\author{
Astrid Konrad \\ Michael Mähler \\ Stephan Arni \\ Beatrice Flogerzi \\ Sonja Klingelhöfer \\ Frank Seibold
}

\section{Ameliorative effect of IDS 30, a stinging nettle leaf extract, on chronic colitis}

Accepted: 25 May 2004

Published online: 25 August 2004

(C) Springer-Verlag 2004

\begin{abstract}
Background and aims: Anti-TNF- $\alpha$ antibodies are very effective in the treatment of acute Crohn's disease, but are limited by the decline of their effectiveness after repeated applications. The stinging nettle leaf extract, IDS 30 , is an adjuvant remedy in rheumatic diseases dependent on a cytokine suppressive effect. We investigated the effect of IDS 30 on disease activity of murine colitis in different models. Methods: C3H.IL-10-/- and $\mathrm{BALB} / \mathrm{c}$ mice with colitis induced by dextran sodium sulphate (DSS) were treated with either IDS 30 or water. Mice were monitored for clinical signs of colitis. Inflammation was scored histologically, and faecal IL- $1 \beta$ and mucosal cytokines were measured by ELISA. Mononuclear cell proliferation of spleen and Peyer's patches were quantified by ${ }^{3} \mathrm{H}$-thymidine. Results: Mice with
\end{abstract}

chronic DSS colitis or IL-10-/mice treated with IDS 30 clinically and histologically revealed significantly $(p<0.05)$ fewer signs of colitis than untreated animals. Furthermore, faecal IL- $1 \beta$ and mucosal TNF- $\alpha$ concentrations were significantly lower $(p<0.05)$ in treated mice. Mononuclear cell proliferation after stimulation with lipopolysaccharide was significantly $(p<0.001)$ reduced in mice treated with IDS 30 .

Conclusions: The long-term use of IDS 30 is effective in the prevention of chronic murine colitis. This effect seems to be due to a decrease in the Th1 response and may be a new therapeutic option for prolonging remission in inflammatory bowel disease.

Keywords Inflammatory bowel disease · IDS 30 - Murine colitis . $\mathrm{TNF}-\alpha$

\section{Introduction}

Until now, the pathogenesis of inflammatory bowel disease (IBD) is not totally understood. However, in Crohn's disease (CD), genetic, immunological and environmental factors clearly play an important role. One important concept is the imbalance between T-helper (Th) cell subsets with an overreaction of Th1 cells. Various proinflammatory cytokines (especially TNF- $\alpha$ ) are secreted by the mucosa of the intestinal tract during the disease [1]. Furthermore, the cells producing TNF- $\alpha$, as well as the TNF- $\alpha$ concentration in stools, were enhanced [2, 3]. Based on these results, agents have been developed to suppress TNF- $\alpha$ as a new approach in the therapy of $\mathrm{CD}$. An efficient therapeutic strategy for patients with $\mathrm{CD}$ is the intravenous application of anti-TNF- $\alpha$ antibodies (infliximab). Infliximab has been shown to be effective in the treatment of refractory luminal $\mathrm{CD}$, as well as in the treatment of fistulae $[4,5]$. Some patients, however, are refractory to immune suppressive treatment and need repeated infusions of infliximab for maintenance of remission [6]. In addition to the high costs of this therapy, some patients develop side effects such as infusion reactions or infectious complications [7-9]. Finally, a loss of effectiveness has been observed after repeated applications [10]. Another anti-TNF- $\alpha$ approach is the therapy with 
soluble receptors (e.g. etanercept). This recombinant receptor/Fc fusion protein binds to human TNF- $\alpha$, but a placebo-controlled trial revealed no significant clinical benefit in CD [11]. In the search for further anti-TNF- $\alpha$ remedies, a few open-label trials have been published using the teratogen thalidomide, which inhibits the production of TNF- $\alpha$ [12-14]. This medication, however, is rejected by the majority of patients because of its side effects. Therefore, it is necessary to evaluate further strategies leading to a modulation of cytokine expression such as novel anti-TNF- $\alpha$ strategies $[15,16]$.

In this paper we investigate the effects of IDS 30, a stinging nettle leaf extract that is a well-known adjuvant drug in the continuous therapy of rheumatic diseases. Stinging nettle leaf extract was able to reduce pain in the joints and $26 \%$ of patients were able to withdraw their non-steroidal anti-rheumatic (NSAR) medications. IDS 30 is a standardised extract of stinging nettle leaves that potently suppresses TNF- $\alpha$ and IL- $1 \beta[17,18]$. The effects are at least in part due to an inhibitory effect on NF- $\kappa \mathrm{B}$. Inhibition of NF- $\kappa \mathrm{B}$ was not mediated by a direct modification of DNA binding, but rather by preventing degradation of its inhibitory subunit I $\kappa \mathrm{B}-\alpha[19]$. Furthermore, it has been shown that these extracts mediate a switch in cytokine patterns derived from T-helper cells [20]. IDS 30 (Strathmann AG; Hamburg, Germany) is a specially developed lipophilic stinging nettle leaf extract with high concentration of 13-S-hydroxy-9Z, 11E, 15Z-octadecatrienoic acid (13-HOTE). This oxylipin has been identified as a cytokine-suppressive agent in stinging nettle leaves.

In $\mathrm{CD}$, the therapeutic options for maintenance therapy are still limited and most of them are characterised by potential side effects. Thus, we investigated the preventive and therapeutic effect of the orally applied antiTNF- $\alpha$ active medication IDS 30 on murine colitis. The following experimental IBD models were used: interleukin-10 gene-deficient mice (IL-10-/-) developing a spontaneous colitis, and when orally administrated with the dextran sodium sulphate salt (DSS induces acute and chronic colitis) [21]. These models are widely accepted as a reproducible mucosal colonic inflammation in mice [22].

\section{Materials and methods}

Materials

The stinging nettle leaf extract IDS 30 (Hox alpha) was kindly provided by Strathmann AG, Germany. The drug was administered at a final concentration of $0.5 \mathrm{mg} / \mathrm{ml}$ in drinking water. The daily uptake of IDS 30 in mice corresponded to the dose used in humans for the treatment of rheumatoid arthritis.

\section{Animals}

Forty-two BALB/c mice were obtained from Harlan (Horst, The Netherlands). Sixteen homozygous 4-week-old interleukin 10 genedeficient mice (IL-10-/-), generated on a $\mathrm{C} 3 \mathrm{H} / \mathrm{HeJBir}$ genetic background (C3H.IL-10-/-), were housed and bred under specific pathogen-free conditions (individually-ventilated cages, IVC). All provisions for the facility were sterilised by autoclaving. All animal experiments were approved by the Swiss authorities.

Five 8-week-old BALB/c mice were treated with 3.5\% DSS salt (ICN Biomedicals; Aurora, OH, USA) for 5 days to induce an acute chemical colitis. Treatment with IDS 30 was started for the 4 days following the induction of colitis, and the mice were sacrificed on day 9.

Eight 8-week-old BALB/c mice were treated with the prepared IDS 30 drinking solution or water for 7 days, and another set of eight mice received water as a control. On day 8, 3.5\% DSS was administered for 5 days to induce an acute chemical colitis. Treatment with IDS 30 was continued for 4 days following the induction of colitis, and the mice were sacrificed on day 16 .

The chronic DSS colitis was induced by three cycles of $3 \%$ DSS for 4 days. The DSS phase was interrupted by periods of 1 week's treatment with IDS 30 (or water) each time, and a final treatment with IDS 30 (or water) for the last week. Again, eight mice were treated with IDS and eight mice with water as a control in these experiments.

Eight 4-week-old C3H.IL-10-/- mice without clinical signs of colitis received either the water with $0.5 \mathrm{mg} / \mathrm{ml}$ IDS 30 or water alone for 10 weeks, and were sacrificed on day 70 .

\section{Monitoring}

The drinking volume, weight and clinical signs of colitis for each mouse were monitored four times a week (redness of the anus, ulcerations of the anus, weight loss, diarrhoea and bloody diarrhoea).

\section{Histological injury grading}

All mice were sacrificed by $\mathrm{CO}_{2}$ inhalation. Longitudinal halves of colons and caeca were taken in their entirety; the length was measured and fixed in $4 \%$ phosphate-buffered formalin. Samples were embedded in paraffin in toto and sectioned at $5 \mu \mathrm{m}$. Sections were stained with $\mathrm{H} \& \mathrm{E}$ and the slides were scored double-blinded by two different experts (M.M. and B.F.) as previously described [23]. Briefly, the histological score ranged from grade 0 to 3 (Table 1). The intestinal inflammation of each mouse was scored at the proximal, middle and distal colon, and the scores for each section were computed, resulting in a range from 0 to 9 . Furthermore, the intestinal inflammation from the caecum was scored separately and ranged from 0 to 3 .

\section{Faecal sample preparation}

Faecal samples were collected and weighed. Samples were homogenised in $3 \mathrm{ml} / 0.1 \mathrm{~g}$ stool weight in a solution of $1 \mathrm{mg} / \mathrm{ml}$ soy trypsin inhibitor and $1 \mathrm{mg} / \mathrm{ml}$ PMSF (phenylmethylsulphonyl fluoride from Sigma; Buchs, Switzerland) in PBS (phosphate-buffered saline, Sigma). Supernatants were collected after centrifugation at $10,000 \mathrm{~g}$ for $15 \mathrm{~min}$, sterile filtered and stored at $-70^{\circ} \mathrm{C}$ prior to testing. IL- $1 \beta$ concentrations were measured by sandwich ELISA using a commercial test system (R\&D Systems; Abingdon, UK). 
Table 1 Histopathological score

\begin{tabular}{ll}
\hline Score & Characteristics \\
\hline Grade 0 & $\begin{array}{l}\text { No change from normal tissue } \\
\text { Grade } 1\end{array}$ \\
$\begin{array}{l}\text { Mild mucosal hyperplasia; inflammation and/or fibrosis in the lamina propria mucosae; occasional erosions and/or small ulcers } \\
\text { (involving up to a total of 20 crypts) }\end{array}$ \\
Grade 2 & $\begin{array}{l}\text { Moderate mucosal hyperplasia; multifocal areas of inflammation and/or fibrosis extending into the tunica submucosa and } \\
\text { sometimes transmural; crypt abscesses; erosions and ulcers (involving up to a total of } 40 \text { crypts) }\end{array}$ \\
Grade 3 & $\begin{array}{l}\text { Severe mucosal hyperplasia; diffuse areas of inflammation and/or fibrosis extending into the tunica muscularis; crypt abscesses; } \\
\text { erosions and ulcers (involving more than a total of } 40 \text { crypts) }\end{array}$
\end{tabular}

Mucosal cytokine secretion

Longitudinal halves of colons were removed from the control and treated animals, put in cold Hanks-balanced salt solution without calcium and magnesium (HBSS, Life Technologies; Basel, Switzerland), cut into 2- to 4-mm squares and resuspended in complete Roswell Park Memorial Institute (RPMI) medium. Mucosal pieces were then incubated at $37^{\circ} \mathrm{C}$ in $5 \% \mathrm{CO}_{2}$ in the presence or absence of $2 \mu \mathrm{g} / \mathrm{ml}$ lipopolysaccharide (LPS from E. coli, Serotype 055:B5, Sigma, Switzerland). After $6 \mathrm{~h}$, supernatants were collected for measurement of TNF- $\alpha$ and IL- $1 \beta$ and stored at $-70^{\circ} \mathrm{C}$ prior to testing. Cytokine secretion was measured using commercial ELISAs (BD Biosciences Pharmingen; Basel, Switzerland; R\&D Systems).

Isolation of mononuclear cells

Peyer's patches and spleens were taken, placed in HBSS, washed, strained through a mesh sieve (40- $\mu$ m pores) and centrifuged for $8 \mathrm{~min}$ at $1,800 \mathrm{rpm}$. The supernatant was removed and the spleen pellet was resuspended in erythrocyte lysis buffer (ACK-buffer) and cells washed in HBSS three times before reconstitution to $2 \times 10^{6}$ cells $/ \mathrm{ml}$ in complete RPMI medium, supplemented with $5 \%$ heat-inactivated foetal bovine serum and $100 \mathrm{U} / \mathrm{ml}$ antibiotic/antimycotic solution (Life Technologies).

Proliferation assay for mononuclear cells

Mononuclear cells were cultured in complete RPMI medium. Mononuclear cells $\left(2 \times 10^{6} / \mathrm{ml}\right)$ were co-cultivated either with $1-$ $10 \mu \mathrm{g} / \mathrm{ml}$ LPS, $3 \mu \mathrm{g} / \mathrm{ml}$ of the cell mitogen Concanavalin A (Con A, Böhringer; Mannheim, Germany) or $5 \mu \mathrm{g} / \mathrm{ml}$ anti-CD3 (Pharmingen), and incubated for 4 days. Proliferation was determined by ${ }^{3} \mathrm{H}-$ thymidine incorporation (Amersham; Little Chalfont, UK). Cells were pulsed with ${ }^{3} \mathrm{H}$-thymidine for the final $18 \mathrm{~h}$ and harvested (Skatron; Lier, Norway). Incorporated ${ }^{3} \mathrm{H}$-thymidine was quantified by scintillation counting (Beckmann; Fullerton, CA, USA).

\section{Statistical analysis}

The results were expressed as mean \pm standard error of the mean. The significance of the difference in means was determined by the unpaired, two-tailed Student's $t$-test (GraphPadPrism 3.0).

\section{Results}

Ameliorative effect of the stinging nettle leaf extract IDS 30 on disease activity of chronic DSS colitis

The clinical effects of a daily oral treatment with IDS 30 were compared with those in untreated controls in a DSSinduced chronic and acute colitis model. Since a therapeutic effect of IDS 30 in rheumatic diseases was only seen after several weeks of treatment, we investigated the chronic DSS colitis model. As shown in Fig. 1a, in the chronic DSS model, no significant difference in weight over the time of the experiment was observed when comparing mice treated with IDS 30 with untreated mice. However, during the DSS cycles, the loss of weight was earlier and more severe in the control compared with the IDS 30 treatment group with increasing evidence in the repeated DSS phases (not significant). Only the watertreated group (25\%) and not the mice treated with IDS 30 showed more frequently clinical signs of colitis (redness and ulcerations of the anus, bloody diarrhoea; $p<0.05$ ). These observations were supported by the significantly reduced colon length in the water-treated group compared with mice receiving IDS 30 (7.3 vs. $8.2 \mathrm{~cm}, p<0.05)$, and were confirmed by a non-significant, more severe histological score in untreated mice. The mice treated with IDS 30 were scored with $4.25 \pm 0.25$ for the colon, whereas the control group averaged over $4.75 \pm 0.25(p=0.20)$. The caeca were scored with $2.00 \pm 0.0$ vs. $2.5 \pm 0.5$ (Table 2 ).

Amelioration of disease in IL-10-/- mice

In a further experiment on chronic murine colitis over a 10-week period, we applied IDS 30 to 4-week-old C3H.IL-10-/- mice while a control group was treated with water as a placebo. We found a parallel gain in weight in both groups (Fig. 1b). In $29 \%$ of the placebo group, we observed clinical signs of colitis, such as redness of the anus and perianal ulcerations; the same observations were made in only $14 \%$ of the mice treated with IDS 30. Significant discrepancies were measured in the colon length $(8.4$ vs. $7.1 \mathrm{~cm} ; p<0.05)$ and histological injury grading $(p<0.05)$. The colons of mice treated with IDS 30 were scored with $2.5 \pm 0.5$, whereas the control 

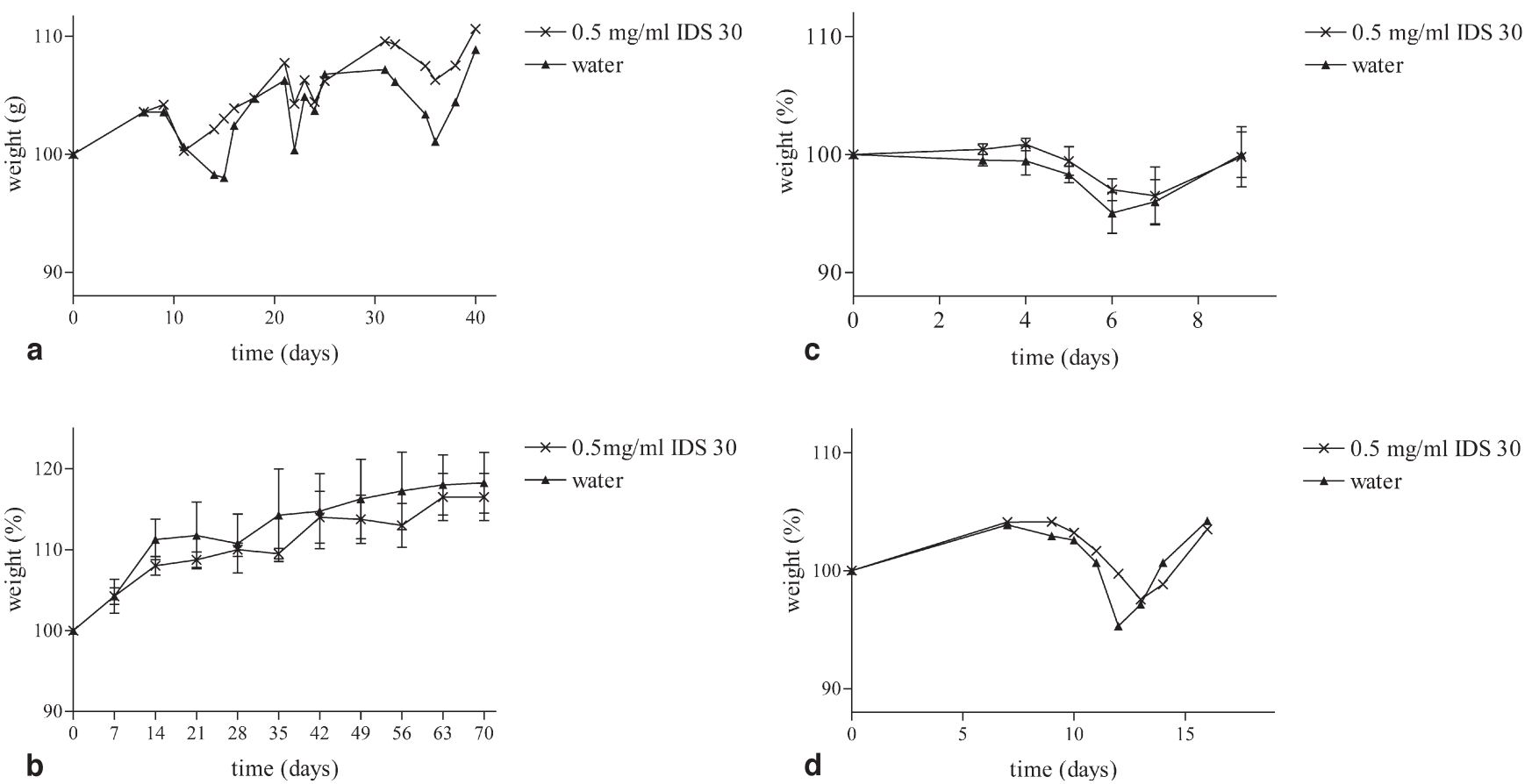

Fig. 1 a Increase in the weight of $\mathrm{BALB} / \mathrm{c}$ mice and $\mathrm{C} 3 \mathrm{H} / \mathrm{He}$ JBir.IL-10-/- mice treated with IDS 30 compared with those treated with water. In the chronic dextran sodium sulphate (DSS) model, colitis was induced after 1 week's pre-treatment with IDS 30 by three cycles of 3\% DSS for 4 days interrupted by a period of 1 week's treatment with IDS 30 (or water). b Increased weight of the C3H.IL-10-/- mice treated for 10 weeks with IDS 30

versus water. In the acute DSS model, $\mathrm{c} B A L B / c$ mice were treated with IDS 30 after colitis had been established or $\mathbf{d}$ mice were pretreated with IDS 30 or water for 1 week before the induction of colitis with DSS. Afterwards, 3.5\% DSS was applied for 5 days, and the treatment was continued for 4 days $(\mathbf{c}, \mathbf{d})$. Note that $n=5$ $\mathrm{BALB} / \mathrm{c}$ mice in experiment $(\mathbf{c}), n=8 \mathrm{BALB} / \mathrm{c}$ mice per group in $\mathbf{a}$, $\mathbf{d}$, and $n=8$ IL-10 knockout mice per group in $\mathbf{b}$

Table 2 Colon length and histological score of treated and untreated animals. DSS dextran sodium sulphate

\begin{tabular}{|c|c|c|c|c|c|c|}
\hline & $\begin{array}{l}\text { IDS 30-treated } \\
\text { mice; colon } \\
\text { length in } \mathrm{cm} \\
(\text { mean } \pm \mathrm{SEM})\end{array}$ & $\begin{array}{l}\text { Water-treated } \\
\text { mice; colon } \\
\text { length in } \mathrm{cm} \\
(\text { mean } \pm \mathrm{SEM})\end{array}$ & $\begin{array}{l}\text { IDS } 30 \text {-treated } \\
\text { mice; score/ } \\
\text { colon } \\
(\text { mean } \pm \text { SEM })\end{array}$ & $\begin{array}{l}\text { Water-treated } \\
\text { mice; score/ } \\
\text { colon } \\
(\text { mean } \pm \text { SEM })\end{array}$ & $\begin{array}{l}\text { IDS 30-treated } \\
\text { mice; score/ } \\
\text { caecum } \\
(\text { mean } \pm \text { SEM) }\end{array}$ & $\begin{array}{l}\text { Water-treated mice } \\
\text { score/caecum } \\
(\text { mean } \pm \mathrm{SEM})\end{array}$ \\
\hline C3H.IL-10-/- mice & $8.4 \pm 0.3 *$ & $7.1 \pm 0.3$ & $2.5 \pm 0.5 *$ & $4.75 \pm 0.25$ & $2.00 \pm 0.0 *$ & $2.75 \pm 0.25$ \\
\hline $\begin{array}{l}\text { Acute DSS model } \\
\text { (BALB/c mice) } \\
\text { therapy }\end{array}$ & $7.0 \pm 0.2$ & $6.8 \pm 0.4$ & $3.6 \pm 0.2$ & $4.00 \pm 0.0$ & $2.4 \pm 0.25$ & $2.6 \pm 0.25$ \\
\hline $\begin{array}{l}\text { Acute DSS model } \\
\text { (BALB/c mice) } \\
\text { prevention }\end{array}$ & $7.1 \pm 0.3$ & $6.9 \pm 0.3$ & $3.25 \pm 0.25$ & $4.00 \pm 0.0$ & $2.25 \pm 0.25$ & $2.75 \pm 0.25$ \\
\hline
\end{tabular}

$* p<0.05$

group averaged over $4.75 \pm 0.25$. Caeca were scored with $2.0 \pm 0.0$ vs. $2.75 \pm 0.25$ (Fig. 2; Table 2).

IDS 30 is not effective in the prevention or amelioration of acute colitis

After the demonstration of the beneficial effect of IDS 30 on chronic murine colitis, we investigated the effect of this component in the acute DSS model. We observed a similar progression in weight in the groups treated and untreated with IDS 30 (Fig. 1c). Neither the clinical signs of colitis nor the colon length differed significantly in either group (7.0 cm [IDS 30] vs. $6.8 \mathrm{~cm}$ [control]; Table 2). We found a non-significant, more severe histological score in untreated mice. The colon scores were $3.6 \pm 0.2$ in the IDS 30 group vs. $4.00 \pm 0.0$ in the water group, and $2.4 \pm 0.25$ vs. $2.6 \pm 0.25$ for the caecum. 


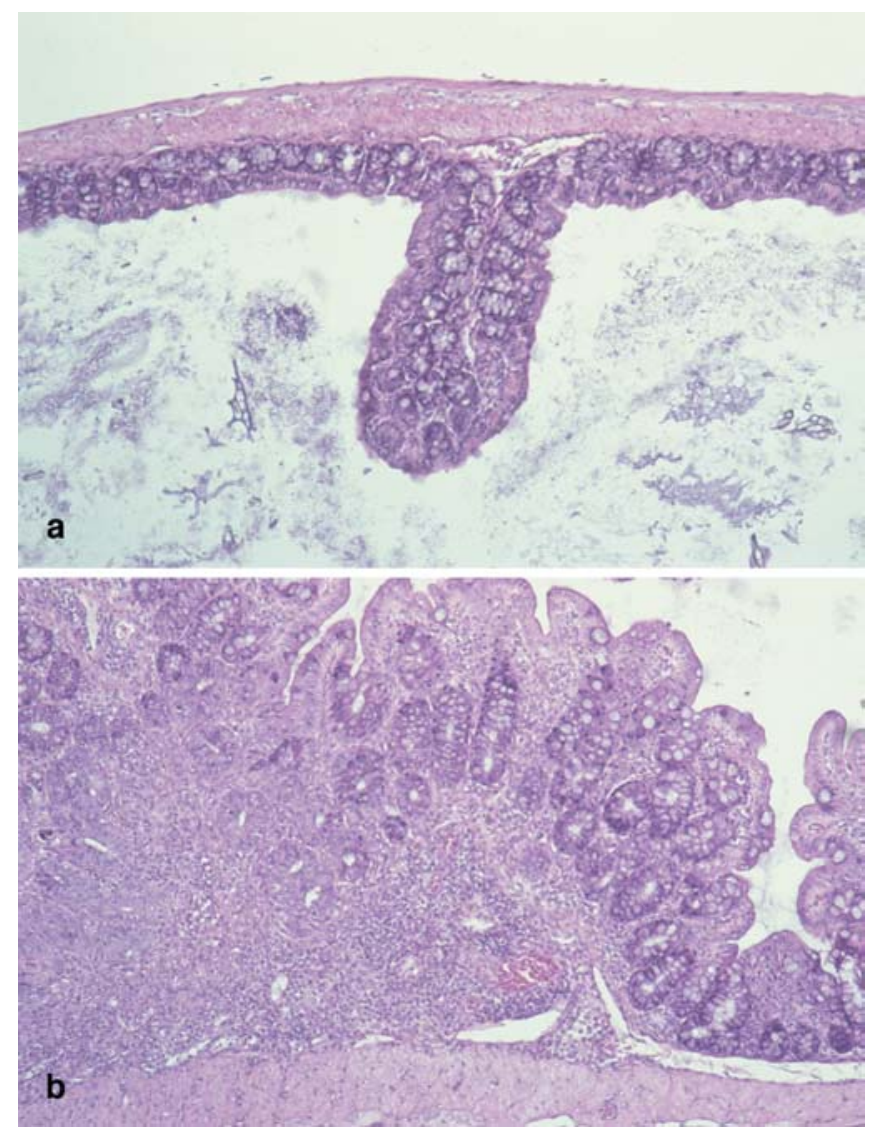

Fig. 2 Histological sections from C3H.IL-10 knockout mice (H\&E, $\times 10)$. The histology of mice treated with IDS 30 was scored with $2.50 \pm 0.50$, whereas the control group averaged over $4.75 \pm 0.25$. a Proximal colon of an IL-10-deficient mouse treated with IDS 30 with normal appearance. b Proximal colon of a water-treated IL-10deficient mouse showing severe inflammatory cell infiltration in the lamina propria and submucosa $(n=8$ mice per group)

When mice were pre-treated for 1 week with IDS 30 or water prior to the DSS application, we found less weight loss in the mice treated with IDS 30 during the DSS phase (not significant) than those in the water-treated group (Fig. 1d). There was no difference in the drinking volume between the two groups. At the end of the DSS feeding, we observed clinical signs of colitis (redness of the anus, diarrhoea and bloody diarrhoea) less frequently in the group treated with IDS 30 than in the control group (38 vs. $50 \%$ ). Neither the clinical signs of colitis nor the colon length differed significantly in either group $(7.1 \mathrm{~cm}$ vs. $6.9 \mathrm{~cm}$ [pre-treatment regimen]; Table 2). We found a non-significant, more severe histological score in untreated mice. The animals pre-treated with IDS 30 were scored $3.25 \pm 0.25$ vs. $4.00 \pm 0.0$ in the water group for the colon, and $2.25 \pm 0.25$ vs. $2.75 \pm 0.25$ for the caecum (Table 2).
Treatment with IDS 30 reduces faecal IL- $1 \beta$ concentration

To verify the disease activity during murine colitis, stool samples were collected at different times, and IL- $1 \beta$ was measured using ELISA. We observed similar concentrations in $\mathrm{BALB} / \mathrm{c}-$ and in $\mathrm{C} 3 \mathrm{H} . \mathrm{IL}-10-/-$ mice prior to treatment (Fig. 3a-c). In the chronic DSS model, there were non-significantly higher IL- $1 \beta$ concentrations in untreated than in treated mice after a period of 14 days (mean $_{\text {water }} 82 \mathrm{pg} / \mathrm{ml}$, mean $_{\text {IDS } 30} 8 \mathrm{pg} / \mathrm{ml} ; p=0.17$; Fig. 3b). After more than 5 weeks of treatment, we observed a significant difference between the group treated with IDS 30 and the untreated group $\left(\right.$ mean $_{\text {water }} 634 \mathrm{pg} / \mathrm{ml}$, mean $_{\text {IDS } 30} 229 \mathrm{pg} / \mathrm{ml} ; p=0.043$; Fig. 3a). In C3H.IL10-/mice we detected significantly $(p=0.02)$ higher levels of IL-1 $\beta$ at day 70 in faecal samples of the untreated group than in the group of mice that received IDS 30 (mean $_{\text {water }}$ $472 \mathrm{pg} / \mathrm{ml}$, mean IDS 3051 pg/ml; Fig. 3b).

In the acute DSS model, higher concentrations of IL- $1 \beta$ at day 11 were measured in the placebo group $\left(\mathrm{mean}_{\text {water }} 260 \mathrm{pg} / \mathrm{ml}\right)$ during acute colitis than in the group treated with IDS 30 (mean $_{\text {IDS } 30} 220 \mathrm{pg} / \mathrm{ml}$; not significant; $p=0.25$; Fig. $3 c$ ).

Reduction of mucosal TNF- $\alpha$ and IL- $1 \beta$ production after IDS 30 treatment in $\mathrm{BALB} / \mathrm{c}$ mice

To investigate the influence of IDS 30 on intestinal cytokine production, colons of treated and untreated $\mathrm{BALB} / \mathrm{c}$ mice from the chronic and acute DSS models were removed to obtain mucosal organ cultures that were cultured in the presence or absence of $2 \mu \mathrm{g} / \mathrm{ml}$ LPS. In the chronic DSS model, there were significantly higher levels of TNF- $\alpha$ in mucosal supernatants of colon $(p=0.035)$ of placebo than in animals treated with IDS 30 after stimulation with LPS (Fig. 4a). Without stimulation, lower concentrations of the pro-inflammatory cytokine TNF- $\alpha$ were detected in supernatants of mucosal organ cultures from mice of the acute DSS model receiving IDS 30 than in untreated animals. However, after stimulation with LPS, no difference was observed between the two groups (Fig. 4b). The investigation of mucosal IL-1 $\beta$ concentrations revealed no differences between treated and untreated animals under baseline conditions. However, the mice treated with IDS 30 in the presence of LPS had significantly lower levels of IL- $1 \beta$ in comparison to the water-treated group of mice. These observations were made in the chronic DSS model $(p=0.044)$ as well as in the acute DSS model ( $p=0.042$; Fig. 4c, d). 

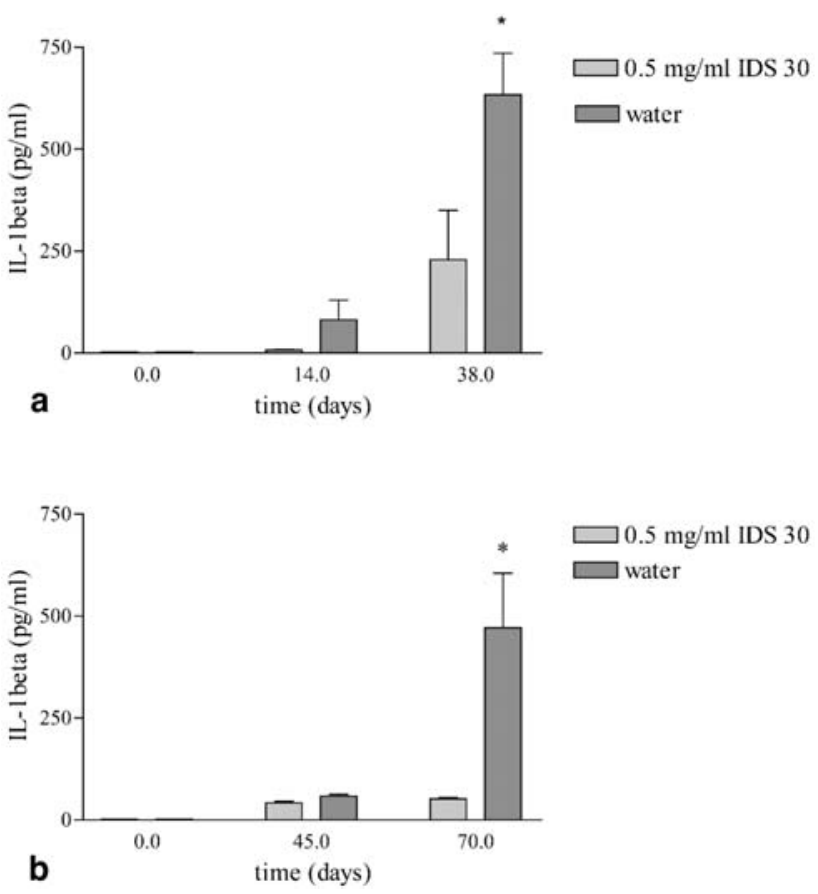

Fig. 3 Stool samples for IL- $1 \beta$ determination were collected prior, during and after treatment with IDS 30 or water. IL- $1 \beta$ concentrations were determined by ELISA. a In the chronic DSS model, the IL- $1 \beta$ levels were significantly lower in the mice treated with IDS 30 at the end of the experiment. b IL- $1 \beta$ concentrations in

\section{Proliferation of mononuclear cell}

Splenic mononuclear cells from BALB/c mice of the chronic DSS model treated with IDS 30 proliferated fewer splenocytes after stimulation with LPS compared with untreated mice (Fig. 5a). We found a significant difference after stimulation with $1 \mu \mathrm{g} / \mathrm{ml}\left({ }^{*} p=0.0272\right)$ and $10 \mu \mathrm{g} / \mathrm{ml}$ LPS $(* * p=0.0038)$. Similar results were obtained in Peyer's patches after stimulation with $1 \mu \mathrm{g} / \mathrm{ml}$ $(* * * p=0.0007)$ and $10 \mu \mathrm{g} / \mathrm{ml}$ LPS $(* * p=0.0019)$. Comparing T-cells of BALB/c mice treated with IDS 30 with those of untreated BALB/c mice, we found no difference in the proliferative response after stimulation with either anti-CD3 or Con A (data not shown). In order to investigate whether the IDS 30 itself has any influence on the proliferative response, we stimulated mononuclear cells from IDS 30-treated and -untreated BALB/c and C3H.IL-10-/- mice using different concentrations (1$10 \mathrm{mg} / \mathrm{ml}$ ) of IDS 30 . No proliferation could be detected (data not shown).

\section{Discussion}

Inflammatory bowel disease and rheumatoid arthritis have partially common pathomechanisms and several medical therapies such as steroids and infliximab are effective in

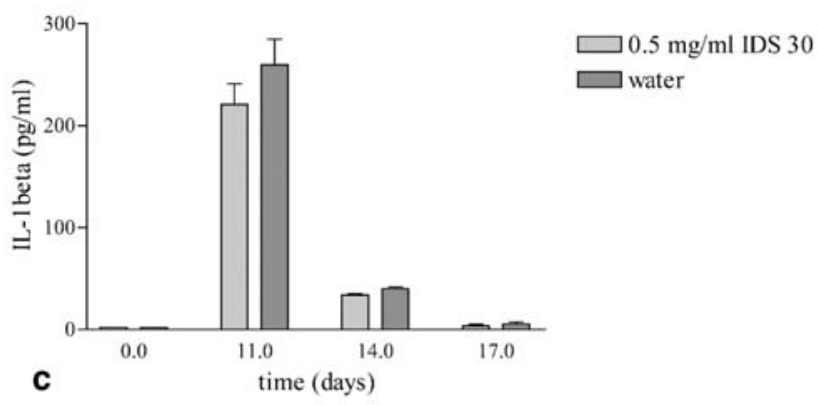

faecal samples from untreated C3H.IL-10-/- mice compared with IDS 30 -treated animals $(* p<0.05)$. $\mathbf{c}$ IL- $1 \beta$ concentrations in faecal samples from IDS 30 and water-treated BALB/c mice prior treatment, in the DSS phase and 5 days after the DSS application in the acute DSS model ( $n=8$ mice per group)

both diseases. IDS 30 is approved as an adjuvant therapy of rheumatic diseases in Germany. This paper has described the biological efficacy of IDS 30 on colitis in three different experimental mouse models for IBD. We found a substantial effect of IDS 30 in two models of chronic colitis. The limited effect of IDS 30 in the treatment of acute colitis may be due to the short duration of treatment with this substance. This effect was also seen in clinical studies with patients suffering from arthritis in which the clinical benefit was detectable after a duration of treatment of several weeks. The clinical observations in this study were confirmed by the measurement of IL- $1 \beta$ in stools, a widely used disease activity marker for murine colitis [24]. We found significantly higher IL- $1 \beta$ concentrations in untreated animals than in treated ones.

Several mechanisms of the stinging nettle leaf extract, IDS 30, have been discussed. This includes the suppression of cytokine production via an inhibition of NF- $\kappa \mathrm{B}$ activation by IDS 30 [19]. In IBD models, the inhibition of NF- $\kappa \mathrm{B}$ or the pro-inflammatory cytokine TNF- $\alpha$ by an antisense oligonucleotide strategy, led to an improvement in the disease $[25,26]$. The effect of IDS 30 on NF- $\kappa \mathrm{B}$ in the context of IBD has not been investigated so far. Furthermore, IDS 30 leads to a suppression of matrix metalloproteinases as shown in chondrocytes in vivo. It is known that the elevation of these metalloproteinases plays a certain role in IBD [27, 28], but the effect of IDS 30 in 

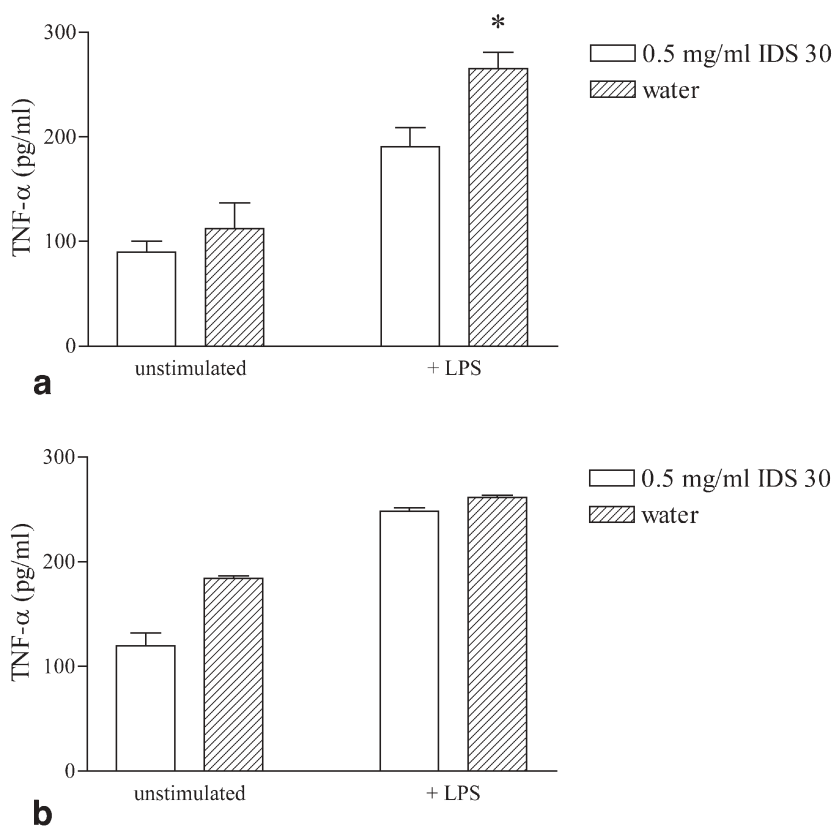

Fig. 4 a, b Mucosal TNF- $\alpha$ and $\mathbf{c}$, d IL- $1 \beta$ secretion in BALB/c mice at the end of the IDS 30 DSS treatment. b Under basal conditions, lower concentrations of the pro-inflammatory cytokine TNF- $\alpha$ were detected in mucosal organ cultures from DSS-treated mice, which received IDS 30 vs. placebo (acute DSS model). a After stimulation with $2 \mu \mathrm{g} / \mathrm{ml}$ lipopolysaccharide (LPS), significantly higher levels of TNF- $\alpha$ were detected in the supernatants of

this context remains to be evaluated. A third important mechanism of IDS 30 may be the decrease in the secretion of pro-inflammatory cytokine TNF- $\alpha$ in the intestinal mucosa. An imbalance of a Th1 and Th2 reaction with a preponderance of a Th1 reaction in CD is a widely accepted pathogenic concept. Madsen et al. have shown that colitis in IL-10-/- mice is associated with high levels of mucosal TNF- $\alpha$. When the mice were housed under germfree conditions, the disease was prevented and the mucosal TNF- $\alpha$ ranged within normal levels [29]. These findings suggest that the IL-10-/- colitis is a result of a Th1-triggered immune response to the mucosal microflora. Furthermore, the clinical data on the effect of an anti-TNF therapy support the importance of TNF- $\alpha$ in the pathogenesis of $\mathrm{CD}[30,31]$. In another study, it was shown that stinging nettle leaf extract is able to inhibit a Th1 reaction in vitro. The production of IL-2 and IFN- $\alpha$ proteins as well as mRNA by mononuclear cells was inhibited in a dose-dependent manner [20]. Furthermore, in vitro data on macrophages showed that TNF- $\alpha$ and IL- $1 \beta$ secretion after LPS stimulation were reduced by the addition of a stinging nettle leaf extract of up to $99 \%$ in a dose-dependent manner [18]. This study clearly demonstrates the downward regulatory effect of IDS 30 on the Th1-triggered immune response in BALB/c as well as in C3H/HeJBir.IL-10-/- mice after stimulation with LPS. We detected a significant decrease in IL- $1 \beta$ as well as less
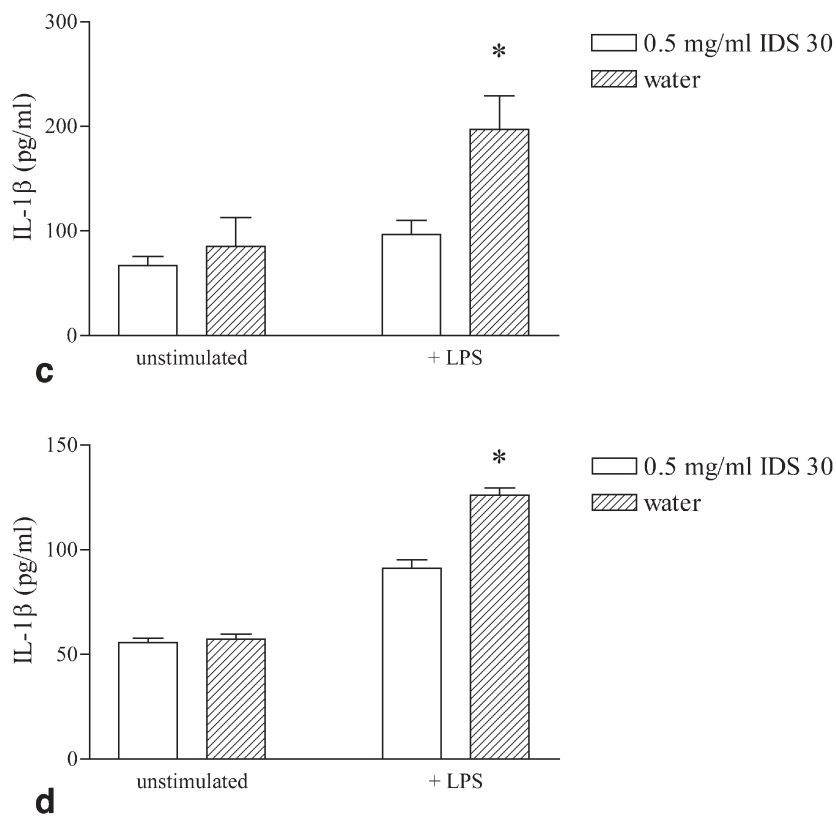

the colon of placebo than in IDS 30-treated animals in the chronic DSS model. c, d For the IL- $1 \beta$ secretions, no difference was observed under baseline conditions, whereas in the presence of LPS, significantly lower levels of IL- $1 \beta$ were observed in IDS 30 -treated mice from the chronic as well as from the acute DSS model $(n=8$ mice per group). *Significant difference $(p<0.05)$ between the groups

TNF- $\alpha$ secretion in the supernatants of the intestinal mucosa in treated animals. In vitro, this effect is mediated by a reduced maturation of dendritic cells and their expression of CD83 and CD86, leading to a reduced T-cell response. One of the most potent inducers of pro-inflammatory cytokines is LPS, the most common pathogen-associated molecular pattern. LPS isolated from $E$. coli is well characterised, it signals through the toll-like receptor complex and induces Th cells to secrete high levels of pro-inflammatory cytokines [32]. In this study, the mononuclear cells of spleens and Peyer's patches from mice treated with IDS 30 proliferated less after stimulation with LPS from $E$. coli than those from watertreated mice. This indicates the suppression of a Th1-type reaction by IDS 30 . Our in vivo models clearly show a reduced mucosal TNF- $\alpha$ and IL- $1 \beta$ secretion triggered by the application of IDS 30 during long-term treatment. In humans, increased secretion of IL- $1 \beta$ and TNF- $\alpha$ is commonly used as a predictive marker for acute relapse. Schreiber et al. demonstrated the positive correlation between high secretion of the pro-inflammatory cytokines TNF- $\alpha$ or IL- $1 \beta$ from lamina propria mononuclear cells and relapse in patients with $\mathrm{CD}$ [33].

Until now, the therapeutic goal in the therapy of IBD is the remission of clinical symptoms as well as the healing of the mucosal inflammation [34]. The therapeutic tools to prolong remission and to reduce mucosal inflammation 

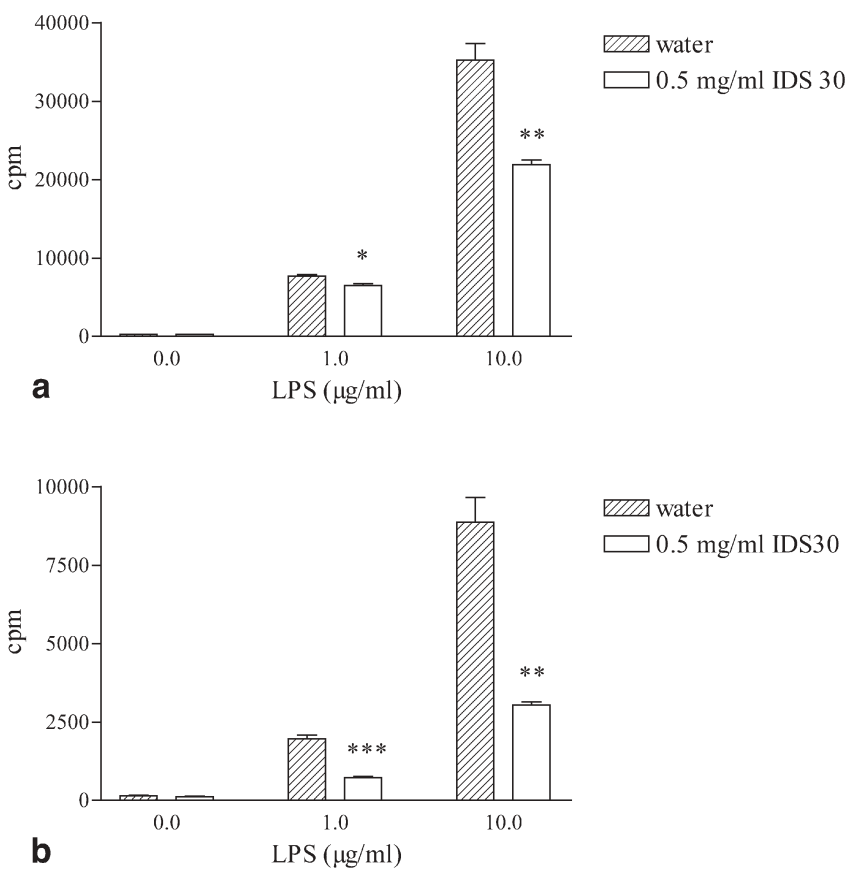

Fig. 5 Effect of IDS 30 on the proliferative response of mononuclear cells in treated and untreated $\mathrm{BALB} / \mathrm{c}$ mice from the chronic DSS model. Mononuclear cells from the spleen and Peyer's patches were isolated from mice treated with IDS-30 or water and stimulated with LPS. The proliferative response was measured by ${ }^{3} \mathrm{H}$-thymidine incorporation. Results are expressed as a mean $(\mathrm{cpm})+$ SEM. a Mononuclear cells of spleens from BALB/c mice treated with IDS 30 proliferated less than splenocytes from untreated animals after stimulation with LPS. This difference is significant for the tested doses of LPS stimulation $(1 \mu \mathrm{g} / \mathrm{ml}$ and $10 \mu \mathrm{g} / \mathrm{ml}$ LPS). b After stimulation, Peyer's patches with LPS $(1 \mu \mathrm{g} / \mathrm{ml}$ and $10 \mu \mathrm{g} / \mathrm{ml}$ LPS) mononuclear cells from IDS 30 -treated animals proliferated less than those from untreated animals $(* p<0.05 ; * * p<0.01 ; * * * p<0.001)$

are still limited. In $\mathrm{CD}$, the most efficient therapies comprise immune suppressive therapies such as azathioprine, 6-mercaptopurine and methotrexate. These substances may maintain about $60 \%$ of the patients in remission [35]. The repeated application of the anti-TNF antibody infliximab is mainly limited by its costs, the intravenous application, infection complications and the possible loss of efficacy following repeated applications. The need for further anti-TNF- $\alpha$ drugs is undisputed, as shown in many recently published experimental studies $[26,36]$. Our data show the TNF- $\alpha$-suppressive effect of IDS 30. However, it could not be compared with infliximab in terms of efficacy and time of response. In arthritis patients, though, this medication is well tolerated. Our data were much more impressive in the chronic murine colitis models than in the acute colitis model. Apparently, IDS 30 needs several days for a clinical effect to be seen. This is supported by the fact that the LPS-stimulated TNF- $\alpha$ release decreased during the IDS 30 treatment. The basal TNF- $\alpha$ was not affected by the treatment with IDS 30, as already described in another study of TNF- $\alpha$ suppression [26]. In that study, the antisense TNF- $\alpha$ suppression was effective in the acute DSS model, but only if higher concentrations than in the chronic colitis model were used. Another explanation might be the different pathophysiological effects caused by acute versus chronic DSS application. Acute DSS colitis is independent of lymphocytes, mainly triggered by toxic effects of DSS on epithelial cells of the colon and can be induced in SCID-mice, whereas in chronic DSS colitis, immunologic mechanisms are involved [37]. Our data support the hypothesis of the beneficial effect by TNF- $\alpha$ inhibition on preventing disease in different models of experimental IBD.

In conclusion, the use of IDS 30 in the experimental treatment of IBD is effective in the prevention and amelioration of chronic murine colitis in DSS-treated BALB/c and in C3H.IL-10-/- mice. This is the first study to demonstrate the beneficial immunomodulatory effect of IDS 30 on experimental IBD in vivo. Therefore, IDS 30 appears to be a new candidate for maintenance therapy in IBD, which needs to be shown in controlled studies with patients.

Acknowledgements This study was supported by the Swiss National Science Foundation (SNF 31-59031.99), by a grant to Astrid Konrad from the Deutsche Forschungsgemeinschaft (KO-2228/2-1) and by Strathmann AG, Hamburg, Germany.

\section{References}

1. Van Deventer SH (1997) Tumour necrosis factor and Crohn's disease. Gut 40:443-448

2. Breese EJ, Michie CA, Nicholls SW, Murch SH, Williams CD, Domizio P et al (1994) Tumor necrosis factor alphaproducing cells in the intestinal mucosa of children with inflammatory bowel disease. Gastroenterology 106:14551466
3. Braegger CP, Nicholls SW, Murch SH, Stephens S, MacDonald TT (1992) Tumour necrosis factor alpha in stool as a marker of intestinal inflammation. Lancet 339:89-91
4. Targan SR, Hanauer SB, van Deventer SJ, Mayer L, Present DH, Braakman T et al (1997) A short-term study of chimeric monoclonal antibody cA2 to tumor necrosis factor alpha for Crohn's disease. Crohn's disease cA2 Study group. N Engl J Med 337:1029-1035 
5. Present DH, Rutgeerts P, Targan S, Hanauer SB, Mayer L, van Hogezand RA et al (1999) Infliximab for the treatment of fistulas in patients with Crohn's disease. N Engl J Med 340:1398-1405

6. Van Deventer SJH (2002) Anti-tumour necrosis factor therapy in Crohn's disease: where are we now? Gut 51:362363

7. Noman M, Baert F, D'Haens G et al (2001) HACA formation after infliximab (remicade) treatment in Crohn's disease is clearly associated with infusion reactions. Gastroenterology 120:A69

8. Baert F, Noman M, Vermeire S, Van Assche G, Haens G, Carbonez A et al (2003) Influence of immunogenicity on the long-term efficacy of infliximab in Crohn's disease. N Engl J Med 348:601-608

9. Keane J, Gershon S, Wise RP, MirabileLevens E, Kasznica J, Schwieterman WD et al (2001) Tuberculosis associated with infliximab, a tumor necrosis factor- $\alpha$ neutralizing agent. N Engl J Med 345:1098-1104

10. Hanauer SB, Feagan BG, Lichtenstein GR, Mayer LF, Schreiber S, Colombel JF et al (2002) Maintenance infliximab for Crohn's disease: the ACCENT I randomised trial. Lancet 359:15411549

11. Sandborn WJ, Hanauer SB, Katz S, Safdi M, Wolf DG, Baerg RD et al (2001) Etanercept for active Crohn's disease: a randomized, double-blind, placebo-controlled trial. Gastroenterology 121:1088-1094

12. Vasiliauskas EA, Kam LY, AbreuMartin MT, Hassard PV, Papadakis KA, Yang H et al (1999) An open-label pilot study of low-dose thalidomide in chronically active, steroid-dependent Crohn's disease. Gastroenterology 117:1278-1287

13. Bauditz J, Wedel S, Lochs H (2002) Thalidomide reduces tumour necrosis factor alpha and interleukin 12 production in patients with chronic active Crohn's disease. Gut 50:196-200

14. Sabate JM, Villarejo J, Lemann M, Bonnet J, Allez M, Modigliani R (2002) An open-label study of thalidomide for maintenance therapy in responders to infliximab in chronically active and fistulizing refractory Crohn's disease. Aliment Pharmacol Ther 16:1117-1124

15. Podolsky DK (2002) Inflammatory bowel disease. N Engl J Med 347:417429
16. Rutgeerts P (2002) A critical assessment of new therapies in inflammatory bowel disease. J Gastroenterol Hepatol 17:S176-S185

17. Teucher T, Obertreis B, Ruttkowski T, Schmitz H (1996) Cytokine secretion in whole blood of healthy subjects following oral administration of Urtica dioica L. plant extract. Arzneimittelforschung 46:906-910

18. Obertreis B, Ruttkowski T, Teucher T, Behnke B, Schmitz H (1996) Ex-vivo in-vitro inhibition of lipopolysaccharide stimulated tumor necrosis factor-alpha and interleukin- 1 beta secretion in human whole blood by extractum urtica dioicae foliorum. Arzneimittelforschung 46:389-394

19. Riehemann K, Behnke B, SchulzeOsthoff K (1999) Plant extracts from stinging nettle (Urtica dioica), an antirheumatic remedy, inhibit the proinflammatory transcription factor NFkappaB. FEBS Lett 442:89-94

20. Klingelhoefer S, Obertreis B, Quast S, Behnke B (1999) Antirheumatic effect of IDS 23, a stinging nettle leaf extract, on in vitro expression of $\mathrm{T}$ helper cytokines. J Rheumatol 26:2517-2522

21. Cooper HS, Murthy SN, Shah RS, Sedergran DJ (1993) Clinicopathologic study of dextran sulphate sodium experimental murine colitis. Lab Invest 69:238-249

22. Elson CO, Sartor RB, Tennyson GS, Riddell RH (1995) Experimental models of inflammatory bowel disease. Gastroenterology 109:1344-1367

23. Konrad A, Mähler M, Flogerzi B, Varga L, Kalousek M, Lange J et al (2003) Amelioration of murine colitis by feeding a solution of lysed E. coli. Scand J Gastroenterol 38:172-179

24. Lindsay JO, Ciesielki CJ, Scheinin T, Hodgson HJ, Brennan FM (2001) The prevention and treatment of murine colitis using gene therapy with adenoviral vectors encoding IL-10. J Immunol 15:7625-7633

25. Neurath MF, Petterson S, Meyer zum Buschenfelde KH, Strober W (1996) Local administration of antisense phosphorothioate oligonucleotides to the p65 subunit of NF-kappaB abrogates established experimental colitis in mice. Nat Med 2:998-1004

26. Myers KJ, Murthy S, Flanigan A, Witchell DR, Butler M, Murray S et al (2003) Antisense oligonucleotide blockade of tumor necrosis factor- $\alpha$ in two murine models of colitis. J Pharmacol Exp Ther 304:411-424
27. Schulze-Tanzil G, de Sousa P, Behnke B, Klingelhoefer S, Scheid A, Shakibaei M (2002) Effects of the antirheumatic remedy hox alpha - a new stinging nettle leaf extract-on matrix metalloproteinases in human chondrocytes in vitro. Histol Histopathol 17:477-485

28. Broer J, Behnke B (2002) Immunosuppressant effect of IDS 30, a stinging nettle leaf extract, on myeloid dendritic cells in vitro. J Rheumatol 29:659-666

29. Madsen KL, Doyle JS, Jewell LD, Tavernini MM, Fedorak RN (1999) Lactobacillus species prevents colitis in interleukin 10 gene-deficient mice. Gastroenterology 116:1107-1114

30. Schreiber S, Campieri M, Colombel JF, van Deventer SJH, Feagan B, Fedorak $R$ et al (2001) Use of anti-tumour necrosis factor agents in inflammatory bowel disease. European guidelines for 2001-2003. Int J Colorectal Dis 16:1-11

31. D'Haens G (2003) Anti-TNF therapy for Crohn's disease. Curr Pharm Des 9:289-294

32. Netea MG, van Deuren M, Kullberg BJ, Cavaillon JM, Van der Meer JW (2002) Does the shape of lipid A determine the interaction of LPS with toll-like receptors? Trends Immunol 23:135-139

33. Schreiber S, Nikolaus S, Hampe J, Hämling J, Koop I, Groessner B et al (1999) Tumour necrosis factor $\alpha$ and interleukin $1 \beta$ in relapse of Crohn's disease. Lancet 353:459-461

34. Arnott IDR, Watts D, Ghosh S (2002) Review article: is clinical remission the optimum therapeutic goal in the treatment of Crohn's disease? Aliment Pharmacol Ther 16:857-867

35. Feagan BG, Fedorak RN, Irvine EJ, Wild G, Sutherland L, Steinhart AH et al (2000) A comparison of methotrexate with placebo for the maintenance of remission in Crohn's disease. North American Crohn's Study Group Investigators. N Engl J Med 342:1627-1632

36. Loher F, Schmall K, Freytag P, Landauer N, Hallwachs R, Bauer C et al (2003) The specific type 4 phosphodiesterase inhibitor mesopram alleviates experimental colitis in mice. J Pharmacol Exp Ther 305:549-556

37. Dieleman LA, Ridwan BU, Tennysonn GS, Beagley KW, Bucy RP, Elson CO (1994) Dextran sulfate sodium-induced colitis occurs in severe combined immunodeficient mice. Gastroenterology 107:1643-1652 